Andreas Damelang*, Martin Abraham

\title{
You Can Take Some of It with You!
}

\author{
A Vignette Study on the Acceptance of Foreign Vocational Certificates and Ethnic Inequality \\ in the German Labor Market \\ Eine Vignettenstudie über den Wert ausländischer Berufsabschlüsse in Deutschland und \\ ethnische Benachteiligungen im Bewerbungsprozess
}

DOI 10.1515/zfsoz-2015-1005

Abstract: This study investigates to what extent skilled immigrants are granted access to the qualified sectors of the German labor market. Vocational certificates are signals which inform the employer about applicants' occupational skills. In this national framework, applicants who hold foreign certificates obviously face some serious problems: First, for German employers, foreign certificates will generally provide less information on an applicant's skills and capabilities. Secondly, employers may use a candidate's country of origin as an index of individual productivity. Based on a factorial survey, we compare the chances of skilled applicants from different countries of origin (Bulgaria, England, France, Portugal, and Turkey) to be invited to an interview for the position of an office management assistant. The results show, as expected, that applicants with German qualifications have a bonus, but that foreign vocational certificates are commonly accepted by German employers; however, they are less highly rated than German degrees. In addition, our results indicate discrimination against non-Western foreign applicants.

Keywords: Labor Market; Foreign Certificates; Ethnic Inequality; Discrimination; Application Process; Factorial Survey.

Zusammenfassung: In der vorliegenden Untersuchung wird die Verwertbarkeit ausländischer Berufsbildungsabschlüsse auf dem deutschen Arbeitsmarkt sowie eine mögliche Benachteiligung von Ausländern im Bewer-

\footnotetext{
*Corresponding author: Andreas Damelang, Friedrich-Alexander Universität Erlangen-Nürnberg, Lehrstuhl für Soziologie und empirische Sozialforschung, Findelgasse 7/9, 90402 Nürnberg, Germany, E-Mail: andreas.damelang@fau.de

Martin Abraham, Friedrich-Alexander Universität ErlangenNürnberg, Lehrstuhl für Soziologie und empirische Sozialforschung, Findelgasse 7/9, 90402 Nürnberg, Germany, E-Mail: martin.abraham@fau.de
}

bungsprozess evaluiert. Hintergrund ist das Problem, dass ausländische Abschlüsse für die Arbeitgeber weniger informativ sind als deutsche Zertifikate. Anhand eines Vignettenexperiments analysieren wir die Wahrscheinlichkeit für ausländische Fachkräfte zu einem Vorstellungsgespräch eingeladen zu werden. Das Herkunftsland der vorgestellten Bewerber - Bulgarien, England, Frankreich, Portugal und Türkei - wird dabei ebenso experimentell variiert wie deren berufliche Qualifikation. Die Ergebnisse zeigen erwartungsgemäß, dass Bewerber mit deutschen Abschlüssen bevorzugt werden. Ausländische Fachkräfte können ihre im Ausland erworbenen Zertifikate zwar auch auf dem deutschen Arbeitsmarkt verwerten, jedoch mit Abschlägen. Des Weiteren deuten die Ergebnisse auf eine Diskriminierung nicht-westeuropäischer ausländischer Bewerber hin.

Schlüsselwörter: Arbeitsmarkt; Ausländische Zertifikate; Ethnische Ungleichheit; Diskriminierung; Bewerbungsprozess; Faktorielles Survey.

\section{Introduction}

The freedom of movement for workers in Europe and the shrinking native labor force are creating an increasing internationalization of the German labor market. Compared with the classic wave of immigration in the 1960s and 1970s, more foreign professionals who were educated and acquired their associate degrees in their countries of origin are applying for a job in Germany. As a consequence, current immigrants are much more highly qualified than in previous decades (Kogan 2011). However, with these increased qualifications, new problems have arisen because these higher qualifications must be assessed and accepted by German employers. Because the German labor market is highly focused on vocationally trained employees, vocational certification increases labor market opportunities and is thus an essential part of successful access to good 
jobs (Gangl 2001; Konietzka 1999). In this system, employers rely especially on vocational certificates to provide information concerning the vocational competencies and commitments of their holders (Abraham et al. 2011; Kerckhoff 2003). Thus, vocational certificates impart information regarding the expected productivity of the applicants during the application process (Bills 2003; Spence 1973). This process leads to the crucial question as to how employers appraise the foreign vocational certificates of immigrants.

If employers do not consider foreign vocational certificates to be equal to German vocational certificates, this effectively depreciates the acquired competencies. As a result, immigrants may end up in a lower sector of the labor market. According to a study by Szydlik (1996) foreign employees are often far better qualified for their jobs than Germans are. Of course, it is not mandatory that human capital that has been acquired abroad be completely transferable to the host country (Friedberg 2000). However, recent empirical studies have shown that, even controlling for competencies that are relevant to the labor market, immigrant workers earn less money than local workers do (Konietzka \& Kreyenfeld 2001; Smoliner 2011; Weins 2010). The authors argue that this difference is due to the lower signal value of foreign certificates. As are as statistic discrimination is concerned, the holders of foreign certificates are rated less productive on average, and consequently, they earn lower wages and hold positions with a lower status. If foreign certificates are recognized as equivalent to German certificates, one can expect positive effects for labor market integration. In Germany, a specific law, the "Professional Qualifications Assessment Act,"1 regulates which foreign certificates are equivalent to their German counterparts. However, because the recognition process is costly and time-consuming, it is chiefly particularly highly qualified immigrants who are seeking access to regulated professions who undergo this formal process (Kogan 2012).

The existing empirical evidence implies the restricted usability of foreign educational certificates in the German labor market. However, the literature shows deficits in two important aspects. First, the studies that focus on inequalities only consider immigrants who have succeeded in entering the German labor market. In cases in which access to employment is initially a critical problem, previous studies have, for example, underestimated the extent

1 In German, this is called the Berufqualifikationsfeststellungsgesetz. For more information, see www.bpb.de/gesellschaft/migration/ kurzdossiers/141848/assessment-of-qualifications-acquired-abroad, retrieved July 22, 2015. of wage inequalities. This underestimation leads to the question as to whether those immigrants who have earned their vocational certificates abroad are perceived by employers as employable skilled workers at all. An answer to this question will provide information concerning the openness of the German labor market for foreign workers, especially in its qualified sectors. Consequently, we focus directly on the employment procedures of firms and compare the likelihood of the applicants from different countries of origin being invited to a job interview. The second deficit is that the empirical literature has rarely considered how the structure and the quality of the respective educational systems in the country of origin influence the evaluation of foreign certificates. Usually, the studies only focus on the average difference between native and foreign workers. If the sample size permits a detailed analysis, individual groups of foreigners are compared with locals. However, we suspect that different educational systems in different countries - and the employers' perception of them - determine the acceptance of foreign certificates by domestic companies. Consequently, we also focus on the differences among the certificates from a variety of foreign countries. We distinguish between immigrants from Bulgaria, England, France, Portugal, and Turkey.

In addition to the acceptance or not of foreign degrees, the question arises whether foreign applicants are discriminated against during the hiring process. The hiring process generally provides an opportunity for discrimination because discrimination is difficult to prove in any given case (Petersen \& Saporta 2004). Indeed, there is considerable evidence of discrimination in the labor market (for a short overview, see, e. g. Andriessen et al. 2012). This evidence shows that foreign applicants are, under otherwise equal conditions, invited less frequently to job interviews than native job seekers. However, to our knowledge, there are no studies that address whether such discrimination is based on a lower assessment of educational degrees or on general attitudes toward people from a particular country.

In this article, we use a factorial survey to empirically examine the acceptance of foreign vocational certificates and potential ethnic discrimination. In this factorial survey, CEOs and firm owners were asked to evaluate several brief, hypothetical descriptions of different potential applicants. The idea is to determine the likelihood of an applicant being invited to a job interview by the respondent. The experimental design of the factorial survey creates the opportunity to employ random variation of the parameters of the particular situation - in this case, the different factors that are relevant to the application. The analysis focuses on the (foreign) vocational certificate and the country of origin, which is also where the certificate 
was acquired. To reduce the complexity of the design, we restrict the study to office management assistants. This job is found in nearly all firms, and in Germany, it is an approved and certified vocational occupation in the vocational training system (VTS). The German VTS is generally organized as a combination of on-the-job training and school attendance, which is the so-called dual system of vocational training. As far as foreign labor markets are concerned, it can be safely assumed that the tasks that are related to office management assistants must also be conducted in foreign firms. ${ }^{2}$

The existing empirical results suggest that applicants with German degrees are preferred over applicants with foreign degrees. However, this comparison does not identify the "true value" of foreign certificates because it is nearly impossible to control empirically for individual productivity beyond vocational training. In particular, it is nearly impossible to control for further unobserved properties such as the employee's plans to eventually return to his country of origin (Bonacich 1972). To determine the real value of foreign professional degrees, we compare the foreign applicants with certificates that have been acquired in their country of origin with the foreign applicants who have not completed any vocational training at home. To control for occupational experience, the fictional applicants in our experimental design are said to have already gathered working experience in this occupation. This design is used to compare the acceptance of the applicants who differ only in the respective vocational degree; hence, it measures the "true value" of these certificates for German employers. The present article is the first attempt to rate the value of foreign degrees in the application process empirically. In addition, we include in our design German and foreign born applicants, both of whom acquired their vocational degrees in Germany. The comparison of these two groups explains the discrimination behavior of the employers. We can, therefore, with our experimental design, separate the effects of the lower acceptance of foreign degrees and the general attitudes toward foreign applicants.

To achieve this goal, we first discuss the application process with a special focus on the role of vocational certificates and ethnic discrimination. Subsequently, we present the survey instrument, which is followed by the

2 The German job titles read "Bürokauffrau/-mann" and "Kauffrau/-mann für Bürokommunikation,” Since August 1, 2014, the training regulations for both occupations have been merged with a new job title, the "Kauffrau/-mann für Büromanagement." empirical results. Finally, we discuss the implications and restrictions of our study.

\section{The process of screening and the role of vocational certificates}

Because we focus on the likelihood of being invited to a job interview, the following theoretical discussion concentrates on the preselection of the applicants. In labor market theory, the selection of applicants is the result of a search process that is characterized by incomplete and asymmetric information (Stigler 1961). Therefore, the applicants' productivity is ex ante largely unknown (Jovanovich 1979) because employers have difficulties in assessing their occupational skills. Consequently, the applicants face the challenge of communicating their skills to the employers in a credible way. One possible solution is the applicant's investment in credible signals (Spence 1973). A credible signal emerges if he or she invests in some type of test that is correlated with his or her performance abilities. In a process of self-selection, if the test is only successfully passed by those with sufficient skills, low performers will not even attempt to acquire the signal. Typically, credible signals are provided by educational and occupational institutions that award certificates. These documents can be considered signals that inform the employer about the occupational skills of the applicants. The informational value is dependent on the reliability and credibility of the test and the institutions that provide the certification.

This theoretical mechanism is especially visible in the German vocational training system. Occupational institutions such as the Chamber of Trades and the Chamber of Industry and Commerce provide standardized rules and a reliable test procedure for vocational training in several hundred occupations. Employees who pass through this system invest in reliable vocational signals as far as occupational skills are concerned. Because employers are integrated in the vocational training system, they estimate the relevant skills fairly well. Consequently, this standardized system of vocational training facilitates labor market choices and considerably reduces the costs of searching (Abraham et al. 2011). An important precondition is the reliability of the signals (Akerlof 1970), that is, the certificates must inform the employer about occupational skills and capabilities. This reliability may vary across occupations and labor market sectors. As described above, certificates in the German system of dual vocational training are highly standardized and reliable. One reason for this reliability is the strong link between the educational sys- 
tem and the labor market in Germany (Allmendinger 1989; Müller \& Shavit 1998). Strong institutions yield a high standardization of educational and especially vocational degrees that are accepted by employers throughout the labor market.

In this national framework, the applicants who hold foreign certificates obviously face a serious problem. For German employers, foreign certificates will generally provide less information on the applicants' skills and capabilities. To begin with, this lack of information occurs because German employers simply have less (if any) information regarding the system of vocational training in a specific country. In addition, vocational education is much less standardized in most countries than in Germany. This lower degree of standardization creates a higher variance of skills for a given certificate and reduces its informational value for German employers as compared to German certificates. Finally, there is empirical evidence that foreign applicants may be subject to discrimination. We discuss these mechanisms in more detail below.

\section{The value of foreign certificates}

Employers' doubts concerning the productivity and the fit of a foreign employee may be due to two things. First, the content of the vocational training may be different than the German equivalent. In this case, the occupational skills and competencies cannot be transferred completely to the job in Germany (Friedberg 2000). This result occurs if the production process is organized differently in each country, and the vocational training does not involve a high amount of general human capital. Especially the German VTS is characterized by a relatively high share of occupational human capital that can be transferred between firms. Thus, graduates of the German VTS have a high level of interplant occupational-specific knowledge. In this respect, the German VTS differs from other European systems (Thelen 2004) despite the attempt to harmonize the VTS's at a European level (CEDEFOP 2009). Alongside the tertiary university system, there are three distinct types of VTS's in Europe (Ebner 2013; Greinert 2005): the dual-corporatist model that is prevalent in Germany; the state-bureaucratic model that is typical for France; and the liberal market model that is found in England. Typically, the liberal market model has vocational training programs that are considerably less standardized than the German and French models. With regard to the vocational specificity of the certificates, which is the level of occupation-specific human capital, the liberal model shows a low level of specificity, the German system shows a high level of spec- ificity, and the French model lies in between. If employers are fully informed regarding these differences, they should be more able to assess the fit of foreign applicants if the foreign VTS is similar to the German system.

The question arises, however, whether employers are sufficiently aware of the structure and quality of foreign VTS and thus are able to seriously evaluate foreign vocational certificates with regard to their occupational match and expected productivity. Spence (1973) distinguishes between signals and indices, whereby indices are ascribed characteristics such as gender and race. Analogously, we can assume that employers use the country of origin as indices for the individual productivity of the applicant. The (ascribed) average productivity of the foreign group to which the respective applicant belongs is then used as a source of information (Lundberg \& Startz 1983). This process applies more if employers are less informed about the foreign VTS or if they simply have no experience with foreign certificates and are unable to evaluate the relation between certificates and productivity. According to statistical discrimination mechanisms, these employers then use easily accessible and evaluable information regarding the country of origin to indicate the productivity of the respective applicant (Aigner \& Cain 1977; Phelps 1972). One obvious indicator to approximate the quality of foreign educational systems is the economic power of the foreign country - where the relation between public investments in education and economic power (GDP) is significant (Topel 1999). Following this line of argument, countries with a higher GDP educate young people better than countries with a lower GDP. As a result, employers rate the average individual productivity of the applicants from economically successful countries higher, which raises the likelihood that they will be invited to a job interview.

Thus, the arguments that favor the value of foreign vocational certificates include the following mechanisms. First, the foreign VTS may be different regarding the standardization and occupational specificity of its training elements. As a result, a poorer occupational match leads to lower productivity and/or higher on-the-job training costs. Second, we assume that assessing individual productivity is difficult despite comparable degrees - in the case of France, even formally recognized degrees. ${ }^{3}$ The mechanisms of statistical discrimination then complement the evaluation of the productivity of the appli-

3 Vocational certificates that are acquired in France are recognized formally and legally as equal to German vocational certificates because of a bilateral agreement (see: www.bmwi.de/BMWi/Redaktion/ $\mathrm{PDF} / \mathrm{G} /$ geimeinsame-erklaerung-abschluesse-deutschland-frankreich, retrieved Sept. 06, 2014). 
cants with foreign certificates. Accordingly, we expect in general that the applicants with a foreign certificate have a lower probability of invitation than do those with a domestic certificate (hypothesis H1). If we observe country-specific patterns, we identify two major mechanisms, the structure of the VTS and the quality of the educational systems. Concerning educational quality, we assume that French and English certificates are more valuable than are certificates from other countries, namely, Bulgaria, Turkey, and Portugal (hypothesis H2). Because of their high degree of standardization, French certificates are likely to face a lower degree of depreciation than English certificates (hypothesis H3a). In the other group, the Portuguese VTS most closely matches the German VTS; therefore, the Portuguese VTS may be expected to be the least depreciated (hypothesis H3b). If applicants with a foreign certificate have a lower probability of invitation than applicants with a domestic certificate, this does not necessarily prove that the foreign certificates will have any signal value at all. Only a comparison of the applicants with and without completed apprenticeships will reveal the signal value of the foreign certificates. A necessary precondition is, of course, that the applicants do not differ in other relevant characteristics, such as work experience, school degrees, and German language skills. If a comparison of the applicants with and without vocational certificates reveals a higher probability of invitation for applicants with a certificate, the difference will be the signal value of the foreign certificates (hypothesis H4).

\section{Discrimination in the application process}

In addition to the functional match between the occupational skills demanded and those supplied, social mechanisms may also play a role in the application process. Social affinity, for example, is a well reported fact (McPherson et al 2001; Wolf 1996). Social relationships are described as affine if individuals in a relationship have certain distinct characteristics that are closely related to one another. People are likely to surround themselves with other people who have similar socio-cultural and personal traits. From immigration research, we know, for example, that friendship networks are likely to be organized along ethnic boundaries (Wimmer 2002). Regarding the application process affinity implies a higher probability of invitation for applicants who are similar to those who are responsible for selecting them. Moreover, nationality is a distinguishing criterion. In addition, if employers have certain ethnic preferences (Becker 1971) they can realize these preferences without worrying about the consequences.
The "opportunity structure of discrimination" (Petersen \& Saporta 2004) claims that discrimination against employees is unlikely to be proven during the application process. In this stage, discrimination based on socio-demographic characteristics is barely visible and difficult to document. Legal action on the part of the rejected applicants is unlikely. Discrimination during the application process may occur, especially if employers have ethnic preferences.

Furthermore, it is a proven fact that employers occasionally ascribe a certain disturbance potential to foreign (male) employees (Diehl et al. 2009). Employers may be afraid that culturally specific traits and communication problems will increase transaction costs and will negatively influence the production process (Lazear 1999). ${ }^{4}$ Numerous studies prove a negative relation between nationality and probability of invitation. In part, this can be explained by individual traits of the foreign applicants like lower school grades (Hunkler 2014). However, there seems to be discrimination beyond productivity differences. A field experiment dealing with the German labor market reveals that applicants with German-sounding names have a callback rate that is $14 \%$ higher than do applicants with Turkish-sounding names (Kaas \& Manger 2011). Similar results are, among others, available for the US (Bertrand \& Mullainathan 2004), England (Wood et al. 2009), the Netherlands (Andriessen et al. 2012), Sweden (Carlsson 2010), and Greece (Drydakis \& Vlassis 2007).

Thus, ethnic preferences and reservations may also result in a lower probability of invitation. Ethnic discrimination occurs if applicants with German nationality have a higher rate of invitation than applicants with a foreign nationality, all else being equal. As described above, there are reasons for depreciating applicants with foreign certificates without considering this discrimination. However, the situation changes if we keep the acquired certificate constant and compare "equal" applicants with and without a foreign nationality. If foreign applicants have a lower rate of invitation than German applicants, ceteribus paribus, this will be strong evidence for discrimination in the application process. We are not aware of any reasonable theory of preference discrimination that predicts the differences among nationalities, and we do not want to claim any ad hoc assumptions based on, for example, cultural and/or social distance. Therefore, we hesitate to verbalize an empirically provable hypothesis concerning national differences. However, the empirical evidence for Germany shows that the Turkish group is especially prone to dis-

4 In contrast, empirical evidence also proves the positive effects of a culturally heterogeneous workforce (see, for example, Buche et al. (2013) for Germany). 
crimination (see, for example, Damelang \& Haas 2006; Seibert \& Solga 2005). A comparison between European countries shows in general that immigrants from more poorly developed countries have on average a higher unemployment risk (Heath et al. 2008). Furthermore, we know from immigration research that reservations grow with increasing cultural and social distance (Ganter 2003; Steinbach 2004). Hence, we expect to find such patterns of ethnic discrimination in our results as well: Foreign applicants from Western European countries should be less prone to discrimination than applicants with Bulgarian or Turkish nationality.

\section{Empirical approach}

To answer our research question, we must collect our own data because standard surveys are unsuitable here for several reasons. First, job applications from immigrants are still few in number, and it is difficult to target incoming immigrants. Second, our research objectives require the identification of unsuccessful applications, which are extremely difficult to assess. Without this information, it is impossible to observe the causal relations and the role of the applicants' characteristics that determine the firm's decision process. Third, in addition to vocational certificates, there are several other factors that most likely influence the willingness to hire a foreign employee. The most important factor is likely to be language skills; the inability to speak German often prevents the success of a job application. Because we are only interested in the role of vocational certificates, we need a way to control effectively for this additional factor. For these reasons, we employed a field experiment. The basic idea is to present hypothetical applicants to employers and inquire the likelihood that the applicants would be invited for a job interview. We define the probability of an invitation for an interview as the dependent variable rather than the actual hiring decision because the actual hiring decision requires insights into personal characteristics and more fine-grained information about relevant skills. For an overview of analogous research approaches, particularly so-called "correspondence tests," see, for example, Andriessen et al. (2012) and Pager (2007). Kaas and Manger (2011) and Schneider et al. (2014) are examples of field experiments that were conducted in Germany. In contrast to correspondence tests, a factorial survey is based on abstract descriptions of the applicants. The data collection consequently does not proceed under real circumstances; instead the participants are aware that they are participating in a study.
This research-ethical aspect is a substantial advantage of our survey method as compared to correspondence analyses (see also Riach \& Rich (2004) and Kühn et al. (2013)). Furthermore, the factorial survey method is more flexible because we can vary several of the applicant's characteristics simultaneously. ${ }^{5}$ The next section is an extensive description of the survey instrument and the realization of the survey.

\section{Survey instrument}

To evaluate the perception of foreign vocational certificates, we employ a factorial survey. A factorial survey is a combination between an experiment and survey research (Steiner \& Atzmüller 2006). Each respondent evaluates several short hypothetical descriptions of situations (vignettes) whose attributes (dimensions) vary experimentally on a defined number of levels (Sauer et al. 2011). Because all the dimensions and their respective levels are combined with one another, the dimensions of the vignette are not correlated (Rossi \& Anderson 1982). This orthogonal design allows the estimation of effect sizes for each dimension (Wallander 2009). The factorial design allows us to estimate the causal effects of the stimuli that are varied in the vignette based on the statements of the respondents. A substantial advantage of the factorial design is that the experimental logic can be implemented in a classical survey.

In detail, our factorial survey attempts to estimate the probability of an invitation to a job interview for foreign certificate holders and to analyze the role of individual characteristics. We present to each respondent a set of vignettes that are comprised six fictive applicants. ${ }^{6}$ For each applicant, the respondent is then asked to rate the probability on a 7-point scale that ranged from 'very likely' to 'very unlikely.' Each vignette or description represents an applicant that we present sequentially to the respond-

5 Beyond this, correspondence tests have an additional disadvantage. With correspondence tests, it is only possible to observe whether the fictive applicant was invited, but it is not possible to control for the field of candidates. If a real, non-fictive foreign candidate is preferred over the fictive applicant, this is interpreted within this research as discrimination. In contrast, a vignette study allows us to control for the field of applicants, for example, by simulating a given number of competitors for the job. Furthermore, it is possible to observe which employer evaluates which vignette and what his or her reaction to each vignette is.

6 For similar research designs see, for example, de Wolf \& van der Velden (2001), Di Stasio (2014), Di Stasio et al. (2015), and Vicari \& Zmugg (2015). 
ents. ${ }^{7}$ Thus, the participants evaluate each applicant separately. As a general condition, the vacancy has to be filled as soon as possible.

We limit our experimental design to a single occupation that required vocational training in Germany, in this way keeping the occupational characteristics constant and ensuring that our results were not biased by any of these (unobserved) characteristics. We restrict the design and, therefore, the evaluation of the value of the foreign certificates to office management assistant. The occupation of office management assistant has several advantages. First, this occupation is not regulated, which means that a specific vocational certificate is not required to apply for these jobs. Second, the tasks that are required in this occupation are only moderately specific, especially when compared with tasks in industry and the skilled trades. Thus, foreign professionals without experience in Germany can, in principle, also work in this occupation. Third, office management assistant is one of the most popular among the occupations that require vocational training, and nearly every company has such positions. Consequently, an occupation-specific sample is not necessary. Table 1 describes all the dimensions and levels of the factorial survey undertaken.

The main focus in our experimental design is on the dimensions "country of origin/nationality" and "vocational certificate." The dimension "vocational certificate" has the following three levels: "certificate acquired in Germany", "certificate acquired in home country", and "no certificate acquired in home country". By comparing the applicants at the different levels, we can draw conclusions about the value of foreign certificates. In particular, the comparisons of applicants who have not acquired a certificate in their home country with those applicants who have provide insights into the value of foreign certificates. Comparing the applicants with foreign and those with German certificates with one another can also show to what extent foreign certificates are depreciated. We select the different countries of origin based on the typology of the VTS that are described in section 2. England, France, and Germany are countries whose training elements differ, in theory, with regard to vocational specificity and standardization. Furthermore, we include Portugal in our design because its VTS is similar to the German VTS but is currently under development (IHK 2014). Bulgaria represents a country that was recently added to the European Union (EU); it is also currently one of the largest countries of origin (Migrationsbericht 2012). Vocational training in Bulgaria
Table 1: Dimensions and levels of the factorial survey

\begin{tabular}{ll}
\hline Dimensions & Levels \\
\hline Country of origin/ & Bulgaria \\
England & France \\
& Germany \\
& Portugal \\
& Turkey \\
\hline Vocational certificate & certificate acquired in Germany \\
& certificate acquired in home country \\
& no certificate acquired in home country \\
\hline Work experience & 2 Years \\
& 5 Years \\
\hline Age & 21 Years \\
& 26 Years \\
\hline Last employer & local medium-sized company \\
& large, international company \\
\hline Type of advertised position & tenured \\
& temporary substitute for employee on \\
& maternity leave \\
\hline Number of applications & small \\
& large \\
\hline According & \\
&
\end{tabular}

According to the description in the vignettes, the last employer is located in Germany if the certificate is acquired in Germany, otherwise, in the country of origin.

Excluded combinations

- All persons whose country of origin/nationality is German(y) acquired their occupational degree in Germany (the two levels referring to „home country“ are excluded).

- We excluded the combination 21 years old and 5 years of work experience.

is organized primarily in schools (IHK 2014). Finally, we include Turkey because it is the most important foreign group in Germany. Vocational training in Turkey is also organized primarily in schools (IW 2014). Furthermore, Turkey and Bulgaria are countries that are not members of the EU-15. The selection of the countries also relies on empirical evidence that some ethnic groups are more prone to ethnic disadvantages than others (Heath et al. 2008). Another important dimension of our factorial survey is the "work experience" of the applicants. All applicants have been employed as office management assistant for at least two or five years. This ensures that both applicants with and without vocational certificates have occupation-specific work experience. Furthermore, we varied the dimen- 
sions "age," "last employer," "number of applications," and "type of advertised position" (see table 1$){ }^{8}$

Finally, we keep some general conditions constant in our experimental design. All applicants are females because office management assistant is a female dominated occupation (Hausmann \& Kleinert 2014). We want to exclude unintended gender effects, which may occur if males apply for jobs in female-dominated occupations (and vice versa) (Budig 2002). Furthermore, all applicants have a secondary school certificate or similar and are fluent in written and oral German. These characteristics ensure that language skills do not bias the probability of invitation. Figure 1 shows an applicant who holds a foreign vocational certificate.

You have advertised a tenured position for an office management assistant.

The number of applications is small.

Among them, there is a 26-year-old female from England. The applicant acquired a certificate as an office management assistant in England and has worked there as an office management assistant for 2 years. Her last job was at a large, international company in England.

How likely is it that you will invite her for an interview?

\begin{tabular}{ccccccr}
\multicolumn{2}{r}{ Very unlikely } & \multicolumn{2}{c}{ please choose one $\rightarrow$} & \multicolumn{2}{c}{ Very likely } \\
1 & 2 & 3 & 4 & 5 & 6 & 7 \\
$\square$ & $\square$ & $\square$ & $\square$ & $\square$ & $\square$ & $\square$
\end{tabular}

Figure 1: Example of the description (vignette) of an applicant with a vocational certificate (the varying dimensions are underlined)

\section{Realization of the survey}

The experimental design requires CEOs or firm owners as informants. To reach them, we use the CORIS data base (Cluster-Orientated Regional Information System). CORIS is a cooperative project of the Institute for Employment Research (IAB) and the University of Regensburg that analyzes the conditions and effects of regional economic clusters (for more information, see Möller \& Litzel 2005). Approximately 1,060 firms from East Bavaria and approximately 850 firms located in Middle Franconia participate

8 The number of all possible vignettes, that is, the combination of all levels is calculated as the Cartesian product of all the dimension levels and represents the vignette universe. The vignette universe consists in our case of 576 descriptions $\left(6^{\star} 3^{\star} 2^{\star} 2^{\star} 2^{\star} 2^{\star} 2\right)$. If we exclude implausible combinations (see hints below in table 1), 384 valid vignettes remain. We divided these 384 vignettes randomly into 64 sets each consisting of 6 vignettes. Afterwards, we assigned one set to each participant randomly. The sequence of vignettes in the sets was also created randomly to avoid sequence effects. in CORIS. Thus, the population under investigation is not a random sample of a defined basic population. This is not an issue in answering the research question because we are only focusing on the factors that are experimentally that is, randomly - assigned in the sample.

The CORIS database consists of approximately 1,600 email addresses and names of contact persons. All of these persons received an invitation by email to participate in the online survey. This email came with a link to an online questionnaire that was administered by Globalpark. A password controlled the access, and each questionnaire could only be answered once. The field work started on June 4, 2014 and closed on July 15, 2014. 187 of the 1,474 contacted firms with valid email addresses participated in the survey (response rate $12.5 \%$ ). The experimental design does not require a high response rate, but it does limit the generalization of the findings. After processing the data, we are able to use 997 vignette judgments from 168 interviewees. ${ }^{9}$

According to the statements in the questionnaire the participants can be characterized as follows: Two-thirds are self-employed or partners and one-third of the participants are employees. $90 \%$ stated that they are responsible for personnel decisions. The median firm size is 22 employees, and more than $60 \%$ of the firms have foreign business relations. Respondents are predominantly male ( $81 \%)$; the mean age is 52 years, and the majority have university degrees.

\section{Empirical results}

In this section, we present the results of our vignette study. First, we examine the average probability of invitation on a descriptive level. Second, a multivariate analysis provides insights concerning the value of foreign certificates by comparing people who have been educated abroad with people who have been educated in Germany. Next, we contrast the applicants with and without a certificate from the home country with one another to identify whether a foreign certificate has any signaling function for German employers at all. If we reveal a significant difference in the probability of invitation, we can trace this result back to the foreign vocational certificate. Third, we discuss discrimination against foreign applicants. If we keep the acquired vocational certificate constant and com-

9 On average, each vignette was answered 2.6 times. The overall statistical power is ensured because we included the full universe of vignettes. 
pare the probability of invitation of the different national groups, we can draw conclusions regarding discriminatory processes.

\section{Average probability of invitation}

Before beginning with the multivariate analysis, a descriptive view on the average probability of invitation for the different groups of applicants is called for. Table 2 shows an average score of 4.6 on a scale that ranges from 1 (very unlikely) to 7 (very likely). Consequently, the majority of our fictive applicants are more likely to receive an invitation than a rejection. This high value is plausible because even for the most unfavorable applicant (young immigrant without a vocational degree but with labor market experience), an invitation is not completely ruled out. If we compare the probability of invitation for the different types of vocational certificates in our vignettes, we observe that a certificate acquired in Germany virtually guaranties an invitation - the average is almost 5.5 points on the seven-point scale. Furthermore, we see a higher probability of invitation for the applicants with a foreign certificate as compared to the applicants who have not acquired a degree abroad (4.5 as compared to 3.7). This result is a first suggestion that foreign certificates are of value in the German labor market.

Table 2: Descriptive evidence of the average probability of invitation (which ranges from $1=$ very unlikely to $7=$ very likely)

average probability of invitation

\begin{tabular}{ll}
\hline All applicants & 4.6 \\
\hline Applicants with German certificates & 5.5 \\
\hline Applicants with foreign certificates & 4.5 \\
\hline Applicants without certificates & 3.7 \\
\hline
\end{tabular}

\section{The value of foreign vocational certificates}

In the multivariate analysis, we run a linear regression with cluster-robust standard errors. ${ }^{10}$ Initially, we empha-

10 When analyzing factorial surveys, one must consider that each respondent evaluates a set of vignettes. Multiple judgments produce clustered observations because there may be an intra-rater correlation (Hox et al. 1991). To address the hierarchical data structure (level 1: vignettes; level 2: respondents), regressions with robust standard errors (Huber-White-sandwich estimator) are appropriate size the value of foreign vocational certificates by focusing on the comparison of the applicants who have and those who have not acquired a vocational certificate in their home country. The applicants who hold a certificate from abroad are the reference group. Furthermore, we also examine the applicants who have a German certificate. Second, we determine the country-specific patterns by running different regression models, one for each country of origin. These country-specific models are comprised only of the applicants from the respective countries. Table 3 presents the overall and the country-specific results of the estimation of the value of foreign certificates.

The result of the full model that includes all applicants meets our expectations. The applicants with a German vocational certificate have a significantly higher probability of invitation as compared to the applicants with a foreign degree. This result is robust for all country-specific regression models, where the coefficients from the different country models of the value "certificate acquired in Germany" do not significantly differ in size from one another. Thus, hypothesis 1 can be confirmed: German employers prefer German vocational certificates over foreign ones.

The French model reveals another interesting insight: although French vocational degrees are formally equivalent to German degrees, French applicants still have a significantly lower probability of invitation. The formal recognition of foreign certificates was intended to be simplified following the Professional Qualifications Assessment Act. However, the results support the idea that even formally recognized foreign certificates are not rated as highly as German certificates. Employing foreign professionals may be perceived as a higher risk; in addition to formal qualification issues, social and cultural aspects may play a role. In addition to that, it has to be noted that the evaluation of German and foreign certificates in our study is limited because - according to the situations described - the applicants with German degrees have already had labor market experience in Germany. In contrast, the applicants with and without certificates from their home country have just immigrated to Germany. The concern that these recent immigrants will potentially return home may also contribute to the lower probability of invitation. Thus, the positive coefficients overestimate the value of a German certificate as compared to foreign certificates. Moreover, the full model also reveals significant negative coefficients for the applicants from Bulgaria, Portugal, and Turkey, which provides

if the dimensions of the vignette are the focus. Multilevel-models are preferred if one wants to estimate the level effects of individual characteristics on the vignette decisions (Maas \& Hox 2004). For a comprehensive discussion see also Auspurg \& Hinz (2015). 
Table 3: The value of foreign vocational certificates

\begin{tabular}{|c|c|c|c|c|c|c|}
\hline & Full model & Bulgaria & England & France & Portugal & Turkey \\
\hline Certificate acquired in Germany & $\begin{array}{l}0.953^{\star * \star} \\
(0.143)\end{array}$ & $\begin{array}{l}1.123^{\star \star \star \star} \\
(0.295)\end{array}$ & $\begin{array}{l}1.053^{\star \star \star} \\
0.274)\end{array}$ & $\begin{array}{l}0.743^{*} \\
(0.349)\end{array}$ & $\begin{array}{c}0.828^{\star} \\
(0.361)\end{array}$ & $\begin{array}{l}0.952^{\star} \\
(0.371)\end{array}$ \\
\hline Certificate acquired in home country & Ref. & Ref. & Ref. & Ref. & Ref. & Ref. \\
\hline $\begin{array}{l}\text { No certificate acquired in home } \\
\text { country }\end{array}$ & $\begin{array}{l}-0.794^{\star \star \star} \\
(0.150)\end{array}$ & $\begin{array}{r}0.101 \\
(0.339)\end{array}$ & $\begin{array}{l}-1.074^{\star \star \star} \\
(0.302)\end{array}$ & $\begin{array}{l}-0.898^{\star} \\
(0.354)\end{array}$ & $\begin{array}{l}-0.789 * \\
(0.369)\end{array}$ & $\begin{array}{l}-1.040^{\star \star} \\
(0.346)\end{array}$ \\
\hline Age: 26 Years & 0.088 & $0.772^{\star}$ & -0.144 & 0.055 & -0.096 & 0.005 \\
\hline (Ref. 21 Years) & $(0.133)$ & $(0.302)$ & $(0.277)$ & $(0.317)$ & $(0.357)$ & $(0.323)$ \\
\hline Work exp.: 5 Years & 0.065 & -0.168 & 0.125 & 0.228 & -0.029 & 0.109 \\
\hline (Ref. 2 Years) & $(0.137)$ & $(0.314)$ & $(0.294)$ & $(0.342)$ & $(0.361)$ & $(0.319)$ \\
\hline Last employer: international & 0.008 & 0.289 & $-0.482^{\star}$ & -0.132 & 0.016 & 0.392 \\
\hline company (Ref. local company) & $(0.111)$ & $(0.259)$ & $(0.241)$ & $(0.265)$ & $(0.297)$ & $(0.279)$ \\
\hline Type of position: & -0.208 & 0.150 & -0.178 & -0.141 & -0.084 & $-0.622^{\star}$ \\
\hline temporary (Ref. tenured) & $(0.111)$ & $(0.256)$ & $(0.238)$ & $(0.265)$ & $(0.287)$ & $(0.275)$ \\
\hline Number of applications: & -0.005 & 0.044 & -0.239 & 0.158 & -0.150 & 0.014 \\
\hline large (Ref. small) & $(0.112)$ & $(0.260)$ & $(0.242)$ & $(0.270)$ & $(0.293)$ & $(0.268)$ \\
\hline Bulgaria & $\begin{array}{l}-0.815^{\star \star \star} \\
(0.217)\end{array}$ & & & & & \\
\hline \multirow[t]{2}{*}{ England } & -0.317 & & & & & \\
\hline & $(0.211)$ & & & & & \\
\hline \multirow[t]{2}{*}{ France } & -0.390 & & & & & \\
\hline & $(0.216)$ & & & & & \\
\hline Germany & Ref. & & & & & \\
\hline \multirow[t]{2}{*}{ Portugal } & $-0.576^{\star}$ & & & & & \\
\hline & $(0.225)$ & & & & & \\
\hline \multirow[t]{2}{*}{ Turkey } & $-0.788^{\star * \star}$ & & & & & \\
\hline & $(0.223)$ & & & & & \\
\hline Constant & $\begin{array}{l}5.081^{\star \star \star} \\
(0.250)\end{array}$ & $\begin{array}{l}3.190^{\star \star \star \star} \\
(0.387)\end{array}$ & $\begin{array}{l}5.321^{\star \star \star} \\
(0.370)\end{array}$ & $\begin{array}{l}4.737^{\star \star \star} \\
(0.390)\end{array}$ & $\begin{array}{l}4.718^{\star \star \star} \\
(0.382)\end{array}$ & $\begin{array}{l}4.423^{\star \star \star} \\
(0.418)\end{array}$ \\
\hline $\mathrm{N}$ & 997 & 187 & 205 & 177 & 171 & 192 \\
\hline R-Square & 0.176 & 0.133 & 0.227 & 0.153 & 0.115 & 0.201 \\
\hline
\end{tabular}

Coefficients from linear regressions; cluster-robust standard errors in parantheses.

Dependent variable: probability of invitation for a job interview; scale ranges from 1 (very unlikely) to 7 (very likely).

${ }^{\star * \star} p<0.001 ;{ }^{* \star} p<0.01 ;{ }^{*} p<0.05$.

the first indication of discrimination against these national groups. We will continue to discuss this finding in detail in the second part of this section.

Regarding the question as to whether foreign certificates are of value in the German labor market, we compare the applicants with and without foreign certificates. If foreign certificates have no signal value for German employers, we do not expect a significant difference with regard to this criterion. To ensure that people without foreign certificates are also credited with occupation-specific human capital, all applicants were characterized as having already been employed as an office management assistant (see section 3). According to the full model, we can confirm that German employers attribute some value to foreign vocational certificates. If we compare the applicants from abroad with and without a certificate, we observe a 0.8 point lower probability for an invitation to an interview, which is statistically significant. This result also holds true in the country-specific models - with the exception of Bulgaria. The difference between the applicants from Bulgaria with and without certificates is not statistically significant. This result suggests that German employers do not trust the certificates from Bulgaria. The coefficients for "no certificate acquired in home country" from the different country-specific models do not differ significantly from one another regarding their effect size. Thus, Bulgaria has a special status in this study. According to the results, foreign certificates have a lower value than German certificates, but they are not without value in the German labor market and can serve as signals. Applicants with vocational certificates, even non-German certificates, are preferred over applicants without vocational certifi- 
cates - as said, with the exception of the applicants from Bulgaria. Hence, we can confirm hypothesis 4: The difference between "certificate acquired in home country" and "no certificate acquired" is the signal value of the foreign certificates. In addition, the results show that the dimension "labor market experience" has no effect on the probability of invitation and is not relevant to the evaluation of the certificates because the interaction effects between experience and vocational degree show no statistically significant effect. The other dimensions of the vignette have predominantly no statistically significant influence. ${ }^{11}$

What role does the structure and quality of the different vocational training systems (VTS) play when evaluating foreign certificates? The main difference between the various VTS's is the level of interplant occupational-specific knowledge that is imparted to the apprentices. As for England and France, the English system is typically characterized by a very low level of occupation-specific human capital, whereas the French system is much more strongly attached to vocational qualifications. Thus, vocational certificates from France are more similar to German vocational certificates than are English certificates. Furthermore, French degrees are formally equivalent to German degrees according to a bilateral agreement. However, if we compare the coefficient of the level "no certificate acquired in home country" in the English model with the corresponding coefficient from the French model, we see no statistically significant differences in effect size. In addition, the effect size of both constants, which characterizes the average probability of invitation for individuals with a foreign certificate do not differ in their statistical significance from one another. This result offers strong evidence that the structure of the VTS, especially in regard to its occupation-specific focus, is not important when evaluating vocational certificates from different countries. Informants need to be aware of country-specific differences. Thus, hypothesis $3 a$ cannot be confirmed: French certificates do not face a lower degree of depreciation than English ones

Perhaps it is more plausible to assume that informants evaluate the quality of the educational systems differently and, thus, the average productivity of the applicants from abroad. We asked the informants in the accompanying questionnaire to assess the different foreign educational

11 The results remain stable even after controlling for individual and company characteristics. In general, employers evaluate foreign applicants better if the company has adopted diversity policies. Diversity management, in turn, correlates highly with the size of the company. The results are not presented here but can be provided by the authors upon request. systems. Everyone was asked to answer these questions even if they had not yet any experience with foreign educational systems. Our questions attempt to evaluate the subjective assessment of the quality of the educational systems and the equality of opportunity. ${ }^{12}$ Table 4 presents the average assessment of the different educational systems. The values range from 1 (very low) to 10 (very high).

Table 4: Subjective assessment of the quality and the equality of opportunity of the educational systems (values range from 1 = very low to $10=$ very high)

\begin{tabular}{ll}
\hline & $\emptyset$ \\
\hline Bulgaria & 5.26 \\
\hline England & 6.91 \\
\hline France & 7.04 \\
\hline Germany & 7.92 \\
\hline Portugal & 6.43 \\
\hline Turkey & 5.49 \\
\hline
\end{tabular}

In table 4 we observe that the German educational system is rated the highest in regard to its ascribed quality and its equality of opportunity with 7.92 out of 10 points. France and England do not follow far behind with 7.04 and 6.91 points respectively. These results allow us to draw the conclusion that employers trust the educational degrees from these countries and that the corresponding certificates are trustworthy signals for them. The subjective assessment of the Portuguese system, and especially the Turkish and Bulgarian systems, is much lower. The very low value for Bulgaria (5.26 points) corresponds accurately with the results from the regressions that are shown in table 3 , where we see no added value for the Bulgarian certificate. Based on these results, we can conclude that it is not so much the structure but the (subjectively assessed) quality of the educational systems - and with it, the expected average productivity of the applicants from abroad - that underlies the evaluation of foreign certificates. This conclusion supports hypothesis 2: The value of foreign certificates

12 The wording of the questions is as follows: "The quality of the educational systems in the following countries is ...”, and the values range from 1 (very good) to 6 (insufficient). "Gaining higher educational degrees in this country depends, first of all, on one's own performance and not on one's social background," and the values range from 1 (fully agree) to 5 (do not agree at all). To present the results, we recode both values such that the higher values correspond to a better assessment. In the next step, we add both values (the maximum score would be 11) and subtract one from the result, which results in a value range from 1 to 10 . 
depends on the economic power and the quality of the educational system. In contrast, applicants with Portuguese certificates - where the vocational training system is similar to the German system - have no advantages compared to applicants with Turkish certificates. This finding, which contradicts our original hypothesis $3 \mathrm{~b}$, shows that the structure of the VTS plays a minor role for the value of foreign certificates.

\section{Discrimination against foreign applicants}

Discrimination against foreign applicants occurs if, ceteribus paribus, they have a statistically significant lower probability of invitation than German applicants. To investigate discrimination, we look at the full model presented in table 3. The coefficients of the different nationalities reveal ethnic inequalities since vocational certificates and other individual characteristics have been held constant. When comparing foreign and German applicants with one another, the consistently negative sign before the coefficients is apparent. However, for the applicants with English and French nationality, the difference is not statistically significant. When we examine the applicants with Bulgarian, Portuguese, and Turkish nationality, we see a statistically significant difference: on average, their probability of invitation is approximately 0.58 to 0.82 points lower on a scale that ranges from 1 to 7 (all other things being equal). This result is a strong suggestion of discrimination against certain but not all foreign groups. ${ }^{13}$

Our analysis only considers a small segment of the labor market. The extent of ethnic discrimination, however, is not similar in all sectors but also depends on job characteristics (Andriessen et al. 2012; Wood et al. 2009). Especially in jobs with customer contact, employers prefer natives over foreigners (Becker 1971). We assume that this preference also holds true for office workers. In addition to our results, other empirical studies have also revealed discrimination in other labor market sectors in Germany. For example, male students with a Turkish-sounding name who apply for an internship have a lower call-back rate than comparable students with a German-sounding name (see Kaas \& Manger 2011). A study by Schneider et al. (2014) reveals that the same group must send signif-

13 In a separate analysis we restricted our sample to those applicants who have a German certificate. The comparison of the probability of invitation of foreign and German applicants both of whom hold a degree that was acquired in Germany shows the same pattern of ethnic disadvantages. Results are available from the authors upon request. icantly more letters of application in their search for an apprenticeship before being invited to an interview.

Both of the studies just cited use correspondence tests that are based on real applications from fictive applicants. As compared to these real-world experiments, a factorial survey is certainly much more abstract. The description of the applicants is based on only a restricted number of characteristics and therefore does not account for all relevant factors as compared to real application documents that include a curriculum vitae and a letter of application. This higher level of abstraction may bias our results concerning discrimination. ${ }^{14}$ Thus, we limit our analysis to the interpretation of the signs. From a methodological point of view, it is worth mentioning that the respondents were aware that they were a part of a study. Thus, we cannot rule out a possible bias toward social responses in the respondents' behavior. However, despite these methodological issues, our results still show discriminatory behavior toward foreign applicants. According to Pager \& Quilian (2005), employer surveys underestimate the real level of discrimination against stigmatized groups - including surveys that address social desirability by using experimental designs. Various studies demonstrate the external validity of factorial surveys by showing that real world behavior and vignette decisions correspond well to one another (e. g. Hainmueller et al. 2015; Nisic \& Auspurg 2009). Thus, the results that are shown in table 3 are consistent evidence of discrimination in the application process. ${ }^{15}$

\section{Summary and discussion}

This study evaluates the assessment of foreign vocational certificates and discrimination against foreigners during the job application process. Using a factorial survey, we

14 For example, since we do not mention the final grade in our vignette design we cannot rule out the possibility that recruiters may believe that native applicants have better grades on average than foreign applicants. Besides, recruiters may ascribe higher language skills to native speakers even if foreign applicants are fluent in both written and oral business German. These ascribed signals of productivity may then contribute to the explanation of national differences in our model as well. In any case, this would not explain the differences between countries and the within-country-effect of certificates. 15 Hunkler (2014) analyzes reliable firm data on access to vocational training schemes and shows that lower test scores and a less efficient application strategy, e.g. with poor timing of the application, cause ethnic inequalities rather than discrimination by employers. In case of commercial training schemes ("kaufmännische Ausbildungen”), however, unexplained ethnic disadvantages of female applicants remain in his analysis. This corresponds with our results. 
present a number of fictive applicants to employers for a position as an office management assistant. The main differences between the applicants are their country of origin and the type of vocational certificate which they have; they all have in common that they have work experience as an office management assistant. The participants of the study are asked to evaluate the probability of inviting the applicants to a job interview. The analysis shows - as expected - that invitations are most likely for applicants who hold a German vocational certificate. A comparison of persons with and without certificates from their countries of origin reveals that foreign degrees also have a certain value. Employers invite persons with a foreign vocational certificate more often than persons without any such certificate. Even if German degrees are preferred, immigrants still profit from their foreign certificates in the German labor market. In addition, the study demonstrates discrimination against foreign applicants during the application process. If the variable vocational certificate is held constant, non-German applicants have a lower probability of being invited, though Western Europeans (French, English) are an exception.

Thus, the results turn out to be mixed. Although foreign vocational certificates are accepted among German employers, they are viewed as less valuable than German degrees. This also applies to French degrees even though they are legally equivalent to German degrees. We can conclude that access to the qualified sectors of the labor market is rather difficult for workers with foreign certificates. In addition, the results indicate the presence of discrimination against foreign applicants.

This study provides only some first insights into the signal value of foreign certificates and how they structure access to qualified occupational labor market sectors. Extended research could, for example, vary the gender of the applicants, include German applicants with a foreign certificate, and ask foreign employers in Germany about their evaluation of foreign certificates in order to reveal further insights. Furthermore, future research should focus on different occupations, especially taking into regard occupation-specific tasks. In this way, we can gain greater and more differentiated information on the value of foreign certificates. We assume that the transferability of job-related human capital and the acceptance of foreign professionals are higher in technical jobs and the skilled trades than in service occupations, especially because service occupations require a high level of communicative and interactive tasks. Furthermore, imminent or existing shortages of skilled labor in certain sectors may increase the pressure on companies to recruit foreign workers.
This brief outlook indicates that the survey's restriction to one single occupation reveals the need to address many additional research questions whose answers may gradually extend the understanding of the handling and the acceptance of skilled foreign workers in the German labor market. In closing we wish to discuss some methodical consequences. For this specific research approach, a factorial survey is advantageous because the assessment of applicants with different characteristics is easy and cost-effectively observable. However, as in any experimental approach, one must discuss whether hypothetical action is transferable to real life situations. A comparison with the results from controlled field experiments provides initial indications that real and hypothetical actions correspond when selecting applicants. Further research could begin here and attempt to support these experimental results systematically with field data.

Acknowledgement: We especially want to thank Victoria Vockentanz, Nicole Litzel, and Lutz Eigenhüller for their help in conducting the survey, also two anonymous reviewers as well as the editors for helpful comments and suggestions. Financial support from the DFG-SPP 1764 "The German Labor Market in a Globalized World" is gratefully acknowledged.

\section{Literature}

Abraham, M., A. Damelang \& F. Schulz, 2011: Wie strukturieren Berufe Arbeitsmarktprozesse? Eine institutionentheoretische Skizze. LASER Discussion Paper 55. Nürnberg.

Akerlof, G. A., 1970: The Market for “Lemons”: Quality Uncertainty and the Market Mechanism. The Quarterly Journal of Economics 84: 488-500.

Allmendinger, J., 1989: Educational Systems and Labor Market Outcomes. European Sociological Review 5: 231-250.

Aigner, D. J. \& G. C. Cain, 1977: Statistical Theories of Discrimination in Labor Markets. Industrial and Labor Relations Review 30: 175-187.

Andriessen, I., E. Nievers, J. Dagevos \& L. Faulk, 2012: Ethnic Discrimination in the Dutch Labor Market: Its Relationship with Job Characteristics and Multiple Group Membership. Work and Occupations 39: 237-269.

Auspurg, K. \& T. Hinz, 2015: Factorial Survey Experiments. Thousands Oaks, CA: Sage, Series: Quantitative Applications in the Social Sciences 175.

Becker, G. S., 1971: The Economics of Discrimination, $2^{\text {nd }}$ ed. Chicago: University of Chicago Press.

Bertrand, M. \& S. Mullainathan, 2004: Are Emily and Greg More Employable than Lakisha and Jamal? A Field Experiment on Labor Market Discrimination. American Economic Review 94: 991-1013. 
Bills, D. B., 2003: Credentials, Signals, and Screens: Explaining the Relationship between Schooling and Job Assignment. Review of Educational Research 73: 441-469.

Bonacich, E., 1972: A Theory of Ethnic Antagonism: The Split Labor Market. American Sociological Review 37: 547-559.

Buche, A., M. Jungbauer-Gans, A.-K. Niebuhr \& C. Peters, 2013: Diversität und der Erfolg von Organisationen. Zeitschrift für Soziologie 42: 483-501.

Budig, M., 2002: Male Advantage and the Gender Composition of Jobs: Who Rides the Glass Escalator?. Social Problems 49: 258-277.

Carlsson, M., 2010: Experimental Evidence of Discrimination in the Hiring of First- and Second-generation Immigrants. Labour 24: 263-278.

CEDEFOP (ed.), 2009: Continuity, Consolidation and Change. Towards a European Era of Vocational Education and Training. Luxembourg.

Damelang, A. \& A. Haas, 2006: Arbeitsmarkteinstieg nach dualer Berufsausbildung. Migranten und Deutsche im Vergleich. IAB-Forschungsbericht 17/2006. Nürnberg.

de Wolf, I. \& R. van der Velden, 2001: Selection Processes for Three Types of Academic Jobs: An Experiment among Dutch Employers of Social Sciences Graduates. European Sociological Review 17: 317-330.

Diehl, C., M. Friedrich \& A. Hall, 2009: Jugendliche ausländischer Herkunft beim Übergang in die Berufsausbildung: Vom Wollen, Können und Dürfen. Zeitschrift für Soziologie 38: 48-67.

Di Stasio, V., 2014: Education as a Signal of Trainability: Results from a Vignette Study with Italian Employers. European Sociological Review 30: 796-809.

Di Stasio, V. \& K. Gërxhani (2015): Employers' Social Contacts and Their Hiring Behavior in a Factorial Survey. Social Science Research 51: 93-107.

Drydakis, N. \& M. Vlassis, 2007: Ethnic Discrimination in the Greek Labour Market: Occupational Access, Insurance Coverage, and Wage Offers. Working Paper 0715, University of Crete, Department of Economics.

Ebner, C., 2013: Erfolgreich in den Arbeitsmarkt?, vol. 960. Frankfurt: Campus Forschung.

Friedberg, R., 2000: You Can't Take It with You? Immigrant Assimilation and the Portability of Human Capital. Journal of Labor Economics 18: 221-251.

Gangl, M., 2001: European Perspectives on Labour Market Entry: A Dichotomy of Occupationalized versus Non-Occupationalized Systems. European Societies 3: 471-494.

Ganter, S., 2003: Soziale Netzwerke und interethnische Distanz. Theoretische und empirische Analysen zum Verhältnis von Deutschen und Ausländern. Opladen: Westdeutscher Verlag.

Greinert, W. D., 2005: Mass Vocational Education and Training in Europe. CEDEFOP Panorama Series 118. Luxembourg.

Hainmüller, J., D. Hangartner \& T. Yamamoto, 2015: Validating Vignette and Conjoint Survey Experiments against Real-world Behavior. Proceedings of the Nation Academy of Sciences 112: 2395-2400.

Hausmann, A.-C. \& C. Kleinert, 2014: Berufliche Segregation auf dem Arbeitsmarkt: Männer- und Frauendomänen kaum verändert. IAB-Kurzbericht 09/2014. Nürnberg.

Heath, A. F., C. Rothon \& E. Kilpi, 2008: The Second Generation in Western Europe: Education, Unemployment, and Occupational Attainment. Annual Review of Sociology 34: 211-235.
Hox, J. J., I. G. G. Kreft \& P. L. J. Hermkens, 1991: The analysis of factorial surveys. Sociological Methods and Research 19: 493-510.

Hunkler, C., 2014: Ethnische Ungleichheit beim Zugang zu Ausbildungsplätzen im dualen System. Wiesbaden: VS-Verlag.

IHK, 2014: Berufsbildungssysteme in Europa, Industrieund Handelskammer zu Berlin. www.ihk-berlin.de/ aus_und_weiterbildung/bildungspolitik/Internationalisierung_ der_Berufsausbildung/813740/EU_Laendervergleich.html. retrieved May 30, 2014.

IW, 2014: bq-Portal. Das Informationsportal für ausländische Berufsqualifikationen, Institut der deutschen Wirtschaft Köln e. V.. www.bq-portal.de/db/berufsbildungssysteme/703 . retrieved May 30, 2014.

Jovanovich, B., 1979: Job Matching and the Theory of Turnover. Journal of Political Economy 87: 972-990.

Kaas, L. \& C. Manger, 2011: Ethnic Discrimination in Germany's Labour Market: A Field Experiment. German Economic Review 13: 1-20.

Kerckhoff, A. C., 2003: From Student to Worker. S. 251-267 in: J. T. Mortimer \& M. J. Shanahan (eds.), Handbook of the Life Course. New York: Kluwer Academic/Plenum Publisher.

Kogan, I., 2011: New Immigrants - Old Disadvantage Patterns? Labour Market Integration of Recent Immigrants into Germany. International Migration 49: 91-117.

Kogan, I., 2012: Potenziale nutzen! Determinanten und Konsequenzen der Anerkennung von Bildungsabschlüssen bei Zuwanderern aus der ehemaligen Sowjetunion in Deutschland. Kölner Zeitschrift für Soziologie und Sozialpsychologie 64: 67-89.

Konietzka, D., 1999: Die Verberuflichung von Marktchancen. Die Bedeutung des Ausbildungsberufs für die Platzierung im Arbeitsmarkt. Zeitschrift für Soziologie 28: 379-400.

Konietzka, D. \& M. Kreyenfeld, 2001: Die Verwendbarkeit ausländischer Ausbildungsabschlüsse: Das Beispiel der Aussiedler auf dem deutschen Arbeitsmarkt. Zeitschrift für Soziologie 30: 267-282.

Kühn, K., D. Liebscher \& A. Klose, 2013: Expertise zu den rechtlichen Aspekten sozialwissenschaftlicher Testing-Verfahren im Rahmen der vom SVR geplanten Studie "Diskriminierung am Ausbildungsmarkt?”. www.svr-migration.de/content/ wp-content/uploads/2014/06/Expertise_fuer_Studie_ Diskriminierung_am_Ausbildungsmarkt.pdf. retrieved October 7, 2014.

Lazear, E. P., 1999: Culture and language. Journal of Political Economy 107: 95-126.

Lundberg, S. J. \& R. Startz, 1983: Private Discrimination and Social Intervention in Competitive Labor Markets. American Economic Review 73: 340-347.

Maas, C. \& J. Hox, 2004: the Influence of Violations of Assumptions on Multilevel Parameter Estimates and their Standard Errors. Computational Statistics \& Data Analysis 46: 427-440.

McPherson, M., L. Smith-Lovin \& J. Cook, 2001: Birds of a Feather: Homophily in Social Networks. Annual Review of Sociology 27: 415-444.

Migrationsbericht, 2012: Migrationsbericht des Bundesamtes für Migration und Flüchtlinge im Auftrag der Bundesregierung, January 2014

Möller, J. \& N. Litzel, 2005: CORIS (Clusterorientiertes Informationssystem) - Clusterpolitik auf solider Basis. S. 17-29 in: 
S. f. W. I. V. u. T. Bayern (eds.), Stadt-Umland-Management. Netzwerke und Clusterbildung - Patentlösung für Staat, Kommune, Wirtschaft und Wissenschaft? Dokumentation der 4. Rosenheimer Stadt-Umland-Gespräche. München.

Müller, W. \& Y. Shavit, 1998: The Institutional Embeddedness of the Stratification Process. A Comparative Study of Qualifications and Occupations in Thirteen Countries. S.1-48 in: Y. Shavit \& W. Müller (eds.), From School to Work. A Comparative Study of Educational Qualifications and Occupational Destinations. Oxford: Clarendon Press.

Nisic, N. \& K. Auspurg, 2009: Faktorieller Survey und klassische Bevölkerungsumfrage im Vergleich - Validität, Grenzen und Möglichkeiten beider Ansätze. S. 211-245 in: P. Kriwy \& C. Gross (eds.), Klein, aber fein!. Wiesbaden: VS-Verlag.

Pager, D., 2007: The Use of Field Experiments for Studies of Employment Discrimination: Contributions, Critiques, and Directions for the Future. Annals of the American Academy of Political Social Science 609: 104-133.

Pager, D. \& L. Quilian, 2005: Waking the Talk? What Employers Say versus What They Do. American Sociological Review 70: 355-380.

Petersen, T. \& I. Saporta, 2004: The Opportunity Structure for Discrimination. American Journal of Sociology 109: 852-901.

Phelps, E. S., 1972: The Statistical Theory of Racism and Sexism. American Economic Review 62: 659-661.

Riach, P. \& J. Rich, 2004: Deceptive Field Experiments of Discrimination: Are they Ethical? Kyklos 57: 457-470.

Rossi, P. H. \& A. B. Anderson, 1982: An Introduction. S. 15-67 in: P. H. Rossi \& S. L. Nock (eds.), Measuring Social Judgments, The Factorial Survey Approach. Beverley Hills: Sage Publications.

Sauer, C., K. Auspurg, T. Hinz \& S. Liebig, 2011: The Application of Factorial Surveys in General Population Samples: The Effects of Respondent Age and Education on Response Times and Response Consistency. Survey Research Methods 5: 89-102.

Schneider, J., R. Yemane \& M. Weinmann, 2014: Diskriminierung am Ausbildungsmarkt. Ausmaß, Ursachen und Handlungsperspektiven, Forschungsbereich beim Sachverständigenrat deutscher Stiftungen für Integration und Migration. www. svr-migration.de/content/wp-content/uploads/2014/03/ SVR-FB_Diskriminierung-am-Ausbildungsmarkt.pdf. retrieved Oct. 7, 2014.

Seibert, H. \& H. Solga, 2005: Gleiche Chancen dank einer abgeschlossenen Ausbildung? Zum Signalwert von Ausbildungsabschlüssen bei ausländischen und deutschen jungen Erwachsenen. Zeitschrift für Soziologie 34: 364-382.

Smoliner, S., 2011: Ungleichheiten auf dem österreichischen Arbeitsmarkt. Österreichische Zeitschrift für Soziologie 36: 95-108.

Spence, M., 1973: Job Market Signaling. The Quarterly Journal of Economics 87: 355-374.

Steinbach, A., 2004: Soziale Distanz. Ethnische Grenzziehung und die Eingliederung von Zuwanderern in Deutschland. Wiesbaden: VS.

Steiner, P. M. \& C. Atzmüller, 2006: Experimentelle Vignettendesigns in faktoriellen Surveys. Kölner Zeitschrift für Soziologie und Sozialpsychologie 58: 117-146.

Stigler, G. J., 1961: The Economics of Information. The Journal of Political Economy 69: 213-225.
Szydlik, M., 1996: Ethnische Ungleichheit auf dem deutschen Arbeitsmarkt. Kölner Zeitschrift für Soziologie und Sozialpsychologie 48: 658-676.

Thelen, K., 2004: How Institutions Evolve. The Political Economy of Skills in Germany, Britain, the United States, and Japan. Cambridge: Cambridge University Press.

Topel, R., 1999: Labour Markets and Economic Growth. S. 2943-2984 in: O. C. Ashenfelter \& D. Card (eds.), Handbook of Labour Economics, vol. 3C. Amsterdam: Elsevier.

Vicari, B. \& H. Zmugg, 2015: Die Befragung „Betriebliche Personalpolitik und offene Stellen“. FDZ-Methodenreport 13/2015. Nürnberg.

Wallander, L., 2009: 25 Years of Factorial Surveys in Sociology: A Review. Social Science Research 38: 505-520.

Weins, C., 2010: Kompetenzen oder Zertifikate? Die Entwertung ausländischer Bildungsabschlüsse auf dem Schweizer Arbeitsmarkt. Zeitschrift für Soziologie 39: 124-139.

Wimmer, A., 2002: Multikulturalität oder Ethnisierung? Kategorienbildung und Netzwerkstrukturen in drei schweizerischen Immigrantenquartieren. Zeitschrift für Soziologie 31: 4-26.

Wolf, C., 1996: Gleich und gleich gesellt sich. Individuelle und strukturelle Einflüsse auf die Entstehung von Freundschaften. Hamburg: Kovac.

Wood, M., J. Hales, S. Purdon, T. Sejersen \& O. Hayllar, 2009: A Test for Racial Discrimination in Recruitment Practice in British Cities. Department for Work and Pensions Research Report 607. London.

\section{Autorenvorstellung}

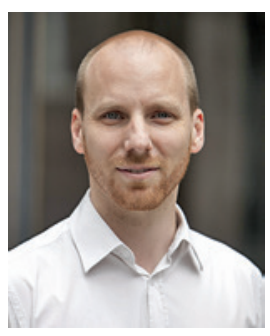

\section{Andreas Damelang}

Friedrich-Alexander Universität ErlangenNürnberg, Lehrstuhl für Soziologie und empirische Sozialforschung, Findelgasse 7/9, 90402 Nürnberg, Germany, E-Mail: andreas.damelang@fau.de

Andreas Damelang, geb. 1979 in Rotenburg (Wümme). Studium der Sozialwissenschaften an der FAU Erlangen-Nürnberg und an der Auckland University of Technology. Promotion an der FAU Erlangen-Nürnberg. Von 2008 bis 2010 Stipendiat im gemeinsamen Graduiertenprogramm des Instituts für Arbeitsmarkt- und Berufsforschung und der Universität Erlangen-Nürnberg, Fachbereich Wirtschaftswissenschaften; seit 2013 Akademischer Rat am Lehrstuhl für Soziologie und empirische Sozialforschung an der Universität Erlangen-Nürnberg.

Forschungsschwerpunkte: Arbeitsmarkt- und Migrationssoziologie. Wichtigste Publikationen: Institutionelle Eigenschaften von Berufen und ihr Einfluss auf berufliche Mobilität in Deutschland (mit F. Schulz \& B. Vicari), Schmollers Jahrbuch 135, 2015; Poverty and the social participation of young people - an analysis of poverty-related withdrawal mechanisms (mit G. Kloß), Journal for Labour Market Research 46, 2013; The Benefits of Migration: Cultural Diversity and Labour Market Success (mit A. Haas), European Societies 14, 2012. 


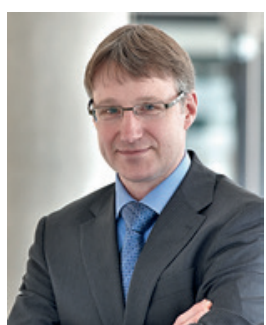

\section{Martin Abraham}

Friedrich-Alexander Universität ErlangenNürnberg, Lehrstuhl für Soziologie und empirische Sozialforschung, Findelgasse 7/9, 90402 Nürnberg, Germany, E-Mail: martin.abraham@fau.de

Martin Abraham, geb. 1964 in Ansbach. Studium der Sozialwissenschaften an der FAU Erlangen-Nürnberg, Promotion ebendort. Habilitation an der Universität Leipzig. Seit 2008 Inhaber des Lehrstuhls für Soziologie und empirische Sozialforschung an der FAU Erlangen-Nürnberg.

Forschungsschwerpunkte: Wirtschafts- und Organisationssoziologie, Arbeitsmarktsoziologie, Familie und Sozialstruktur.

Wichtigste Publikationen: Unemployment and Willingness to Accept Job Offers: Initial Results of a Factorial Survey Approach. (mit K. Auspurg, S. Bähr, C. Frodermann, S. Gundert \& T. Hinz) Journal of Labour Market Research 46, 2013; Migration Decisions Within DualEarner Partnerships: A Test of Bargaining Theory (mit K. Auspurg \& T. Hinz), Journal of Marriage and the Family 72, 2010; Arbeitsmarktsoziologie: Probleme, Theorien, empirische Befunde (herausgegeben mit T. Hinz), Wiesbaden 2005. 